\title{
KONSELING BEHAVIORAL DENGAN TEKNIK SELF MANAGEMENT UNTUK MEMBANTU KEMATANGAN KARIR SISWA SMK
}

\author{
Insan Suwanto ${ }^{1)}$ \\ 1) Program Pascasarjana Universitas Negeri Semarang, Semarang, Indonesia \\ E-mail: insansuwanto@gmail.com
}

\begin{abstract}
Sekolah Menengah Kejuruan (SMK) merupakan salah satu bentuk satuan pendidikan formal yang menyelenggarakan pendidikan kejuruan pada jenjang pendidikan menengah sebagai lanjutan dari Sekolah Menengah Pertama (SMP), MTs, atau lanjutan dari hasil belajar yang diakui setara SMP/MTs. SMK diharapkan bisa menghasilkan lulusan siap kerja, tetapi pada kenyataannya pengangguran terbuka paling banyak dari SMK. Satu diantara tugas perkembangan remaja khususnya siswa SMK adalah tercapainya kematangan karir. Kematangan karir merupakan aspek yang perlu dimiliki siswa untuk menunjang karir dimasa depan. Kematangan karir yaitu sikap dan kompetensi yang berperan untuk pengambilan keputusan karir (B. Hasan, 2006). Siswa SMK dituntut agar dapat melakukan pemilihan karir secara tepat ketika ia dihadapkan dalam proses penjurusan untuk memilih pilihan karir tertentu. Salah satu upaya untuk membantu siswa SMK dalam menghadapi permasalahan kematangan karir yaitu melalui layanan konseling behavioral dengan teknik Self Management. Penulisan ini menggunakan metode kajian literatur, sehingga tujuannya adalah bagaimana konseling behavioral dengan teknik Self Management membantu siswa SMK dalam mengembangkan kematangan karirnya.
\end{abstract}

Kata kunci: Konseling Behavioral; Self-Management; Kematangan Karir

\section{PENDAHULUAN}

Sekolah Menengah Kejuruan (SMK) merupakan salah satu bentuk satuan pendidikan formal yang menyelenggarakan pendidikan kejuruan pada jenjang pendidikan menengah sebagai lanjutan dari Sekolah Menengah Pertama (SMP), MTs, atau lanjutan dari hasil belajar yang diakui setara SMP/MTs. Berbeda dengan Sekolah Menengah Atas (SMA), SMK merupakan salah satu lembaga pendidikan yang mempersiapkan siswanya untuk mampu terjun langsung ke dunia pekerjaan setelah lulus dari sekolah. Rata- rata siswa SMK berkisar antara 15-17 tahun tergolong dalam kategori usia remaja awal [1]. Pendidikan dan kurikulum siswa SMK berbeda dengan siswa SMA. Kurikulum dan tujuan SMK adalah mendidik siswa yang siap bekerja setelah lulus, sehingga pada SMK terdapat berbagai macam bidang yang menjurus pada peningkatan hard skill siswa agar kemampuannya dapat digunakan untuk bekerja setelah lulus.

Menurut teori perkembangan, siswa SMK berada pada tahap eksplorasi periode kristalisasi. Pada periode kristalisasi, remaja semestinya sudah mampu membentuk aspirasi karir dengan mempertimbangkan kebutuhan, minat, kapasitas, dan nilai pribadi. Pada masa ini remaja mulai mengidentifikasi kesempatan dan tingkat pekerjaan yang sesuai, serta mengimplementasikan pilihan karir dengan memilih pendidikan dan pelatihan yang sesuai, akhirnya memasuki pekerjaan yang sesuai dengan pilihannya. Perkembangan karir pada remaja mengalami perkembangan yang besar dan menjadi hal yang sangat penting berkaitan dengan proses pengambilan keputusan akan karir dimana hal ini akan sangat mempengaruhi masa depannya [2].

SMK diharapkan bisa menghasilkan lulusan siap kerja, tetapi pada kenyataannya pengangguran terbuka paling banyak dari SMK. Berdasarkan data Biro Pusat Statistik (BPS) pada Februari 2009, lulusan SMK justru menyumbang pengangguran terbuka paling banyak di Indonesia. Pada Februari 2008, pengangguran terbuka yang terbesar berasal dari lulusan diploma III sebesar 16,35\%, diikuti lulusan SMK sebesar 14,80\%. Selanjutnya, pada Februari 2009 didapatkan hasil yang berkebalikan. Lulusan SMK menyumbang pengangguran terbuka paling tinggi, sebesar 15,69\%, diikuti lulusan diploma III sebesar 15,38\%. Pada bulan Agustus 2009, SMK juga masih menyumbang pengangguran terbuka paling banyak sebesar $14,59 \%$ diikuti lulusan SMA sebesar 14,50\%.

Hasil penelitian menyebutkan siswa kelas X SMAN 2 Majalengka sebagian besar memiliki kemampuan merencanakan karir yang rendah yaitu 27,8 \% [3]. Selain itu berdasarkan hasil penelitian, masalah karir yang dirasakan siswa kelas XI SMKN 7 Bandung berada pada kategori tinggi [4]. Masalah itu meliputi aspek pemahaman minat, nilai-nilai, cita-cita, fisik, kurangnya informasi tentang pengembangan kemampuan dalam bekerja, kesulitan dalam memilih pekerjaan. Di sisi lain siswa SMK tidak mudah menyelesaikan tugas perkembangan karirnya. Fenomena yang terjadi yaitu banyak siswa yang merasa bingung dalam memilih program studi, tidak memahami bakat dan minat yang dimiliki, tidak mampu mengambil keputusan dengan 
tepat, tidak mengetahui cita-cita di masa depan, dan tekanan dari lingkungan.

Satu diantara tugas perkembangan remaja khususnya siswa SMK adalah tercapainya kematangan karir. Seorang remaja akan mencapai kematangan karir apabila pada masa ini mampu menemukan konsep dan jati dirinya. Remaja yang lebih jauh terlibat dalam proses pembentukan identitas lebih sanggup mengartikulasikan pilihan karir mereka dan menentukan langkah berikut untuk mencapai tujuan jangka pendek maupun jangka panjang mereka [1]. Kematangan karir merupakan aspek yang perlu dimiliki siswa untuk menunjang karir dimasa depan., menyatakan kematangan karir yaitu sikap dan kompetensi yang berperan untuk pengambilan keputusan karir [5]. Kematangan karir akan mendasari kemampuan siswa untuk menganalisis peluang karir, yang muaranya adalah pengambilan keputusan karir dengan tepat. Kematangan karir merupakan persiapan awal untuk meraih sukses dalam berkarir [6].

Melalui sikap berarti individu mampu mengambil keputusan terhadap karir dan bertanggung jawab atas segala konsekuensi keputusan, sedangkan kompetensi menunjukkan kemampuan individu memahami kekuatan diri dalam kaitannya dengan dunia pekerjaan. Siswa SMK seyogyanya, dapat melihat gambaran dirinya secara realistis yang mencakup kelebihan dan kekurangan diri baik dari segi fisik, sikap, maupun kognitif serta memiliki pengetahuan tentang minat dan bakatnya sehingga siswa mudah dalam melakukan perencanaan, pemilihan dan keputusan karir. Siswa dituntut agar dapat melakukan pemilihan karir secara tepat ketika ia dihadapkan dalam proses penjurusan untuk memilih jurusan tertentu. Siswa yang memilih jurusan berdasarkan kemampuan dan minat, cenderung memiliki tujuan hidup yang jelas sehingga dapat menjadikan dirinya bersemangat, serius, memiliki motivasi dalam belajar dan selalu berusaha mengembangkan pengetahuan dan kemampuannya pada jurusan yang telah dipilih.

Siswa SMK dalam usahanya untuk mencapai kematangan karir yang diinginkan salah satunya dipengaruhi oleh pengelolaan diri (Self Management) yang dimiliki masing-masing siswa. Self Management merupakan upaya individu untuk melakukan perencanaan, pemusatan perhatian, dan evaluasi terhadap aktivitas yang dilakukan [7]. Terdapat kekuatan psikologis yang memberi arah pada individu untuk mengambil keputusan dan menentukan pilihannya serta menetapkan cara-cara yang efektif dalam mencapai tujuannya. Self management merupakan salah satu model dalam cognitive behavior therapy. Self management meliputi pemantauan diri (self monitoring), reinforcement yang positif (self reward), kontrak atau perjanjian dengan diri sendiri (self contracting), dan penguasaan terhadap ransangan (stimulus control) [8]. Anggapan dasar Self management merupakan teknik kognitif behavioral adalah setiap perilaku manusia itu merupakan hasil dari proses belajar (pengalaman) dalam merespon berbagai stimulus dari lingkungannya. Segenap perilaku manusia itu merupakan hasil dari proses belajar dalam merespons terhadap berbagai stimulus dari lingkungannya.
Salah satu upaya untuk membantu siswa SMK dalam menghadapi permasalahan kematangan karir yaitu melalui layanan konseling behavioral dengan teknik Self Management. Sehingga digunakanlah konseling behavioral dengan teknik Self Management yang bertujuan untuk membantu siswa SMK dalam mengembangkan kematangan karirnya

\section{PEMBAHASAN}

\section{PENGERTIAN KEMATANGAN KARIR}

Kematangan karir merupakan kemampuan individu untuk membuat pilihan karir yang tepat, termasuk kesadaran tentang hal yang dibutuhkan untuk membuat keputusan karir dan tingkat dimana pilihan individu tersebut realistik dan konsisten. Kematangan karir sebagai tingkat di mana individu telah menguasai tugas perkembangan karirnya, baik komponen pengetahuan maupun sikap, yang sesuai dengan tahap perkembangan karir [9].

Individu dikatakan matang atau siap untuk membuat keputusan karir jika pengetahuan yang dimilikinya untuk membuat keputusan karir didukung oleh informasi yang adekuat mengenai pekerjaan berdasarkan pencarian yang telah dilakukan [10]. Kematangan karir adalah keberhasilan individu menyelesaikan tugas perkembangan karir yang khas pada tahap perkembangan karir [11]. Kematangan karir juga merupakan kesiapan afektif dan kognitif dari individu untuk mengatasi tugas-tugas perkembangan yang dihadapkan kepadanya, karena perkembangan biologis, sosial dan harapan dari masyarakat yang telah mencapai tahap perkembangan tersebut. Kesiapan afektif terdiri dari perencanaan karir dan eksplorasi karir sementara kesiapan kognitif terdiri dari kemampuan mengambil keputusan dan wawasan mengenai dunia kerja. Kematangan karir adalah kesiapan dan keberhasilan individu dalam menyelesaikan tahap-tahap perkembangan karir dimana individu telah memiliki pengetahuan mendalam tentang dirinya yang mencakup minat dan bakat serta potensi diri, mampu memilih karir yang sesuai dan memiliki pengetahuan tentang pekerjaan yang telah dipilih, dan dapat membuat keputusan karir dengan baik serta bertanggung jawab terhadap hidup dan pekerjaannya.

Terdapat empat aspek yang dapat digunakan untuk mengukur kematangan karir remaja, yaitu : perencanaan (kesadaran individu bahwa dirinya harus membuat pilihan pendidikan dan karir serta mempersiapkan diri untuk membuat pilihan tersebut), eksplorasi (individu secara aktif menggunakan berbagai sumber untuk memperoleh informasi mengenai dunia kerja umumnya dan untuk memilih salah satu bidang pekerjaan khususnya), kompetensi infromasional (kemampuan untuk menggunakan informasi tentang karir yang dimiliki untuk dirinya, serta mulai mengkristalisasikan pilihan pada bidang dan tingkat pekerjaan tertentu, dan pengambilan keputusan (individu mengatahui apa saja yang harus dipertimbangkan dalam membuat pilihan pendidikan dan karir, kemudian membuat pilihan pekerjaan yang sesuai dengan minat dan kemampuan) [10]. 
Berdasarkan beberapa pengertian di atas, maka dapat disimpulkan kematangan karir adalah kemampuan individu dalam menguasai tugas perkembangan karir sesuai dengan tahap perkembangan karir, dengan menunjukkan perilakuperilaku yang dibutuhkan untuk merencanakan karir, mencari informasi, memiliki wawasan mengenai dunia kerja dan memiliki kesadaran tentang apa yang dibutuhkan dalam membuat keputusan karir.

\section{KONSELING BEHAVIORAL}

Dalam pandangan behavioral, perilaku dibentuk berdasarkan hasil dari segenap pengalamannya yang berupa interaksi individu dengan lingkungan sekitarnya yang membentuk sebuah kepribadian seseorang. Sehingga dapat diubah dengan memanipulasi dan mengkreasikan kondisikondisi belajar. Kepribadian sesorang dengan yang lainnya berbeda-beda karena kenyataannya manusia memiliki pengalaman yang berbeda dalam kehidupannya. Dalam proses konseling, konselor berfungsi sebagai konsultan, penasehat, pemberi dukungan dab fasilitator. Konselor dalam pendekatan ini berfungsi sebagai guru, pengaruh dan ahli yang mendiagnosa tingkah laku yang maladiptif dan menentukan prosedur untuk mengatasi persoalan tingkah laku individu. Para konselor behavioral memandang kelainan perilaku sebagai kebiasaan yang dipelajari. Perilaku dapat diubah dengan mengganti situasi positif yang direkayasa sehingga kelainan perilaku berubah menjadi positif. Modifikasi perilaku menyimpang melalui pengubahan situasi lingkungan positif yang direkayasa sehingga dapat menstimulus terjadinya perilaku positif.

Perubahan perilaku harus diusahakan melalui proses belajar (learning) atau belajar kembali (relearning) yang berlangsung selama proses konseling. Proses konseling pada dasarnya juga dipandang sebagai proses belajar yang dimaksudkan belajar untuk bertingkah laku kearah yang lebih baik dengan bantuan konselor kemudian pada akhirnya klien dapat terbiasa dengan berperilaku yang adaptif meskipun tanpa dibimbing konselor terus-menerus [11].

Berdasarkan penjelasan tersebut maka dapat disimpulkan konseling behavioral adalah suatu teknik dalam konseling yang berlandaskan teori belajar berfokus pada tingkah laku individu untuk membantu konseli mempelajari tingkah laku baru dalam memecahkan masalahnya. Tujuan konseling behavioral yaitu : (1) Menciptakan perilaku baru. (2) Menghapus perilaku yang tidak sesuai. (3) Memperkuat dan mempertahankan perilaku yang diinginkan.

\section{PENGERTIAN SELF MANAGEMENT}

Self management melibatkan pemantauan diri, penguatan yang positif, kontrak atau perjanjian dengan diri sendiri dan penguasaan terhadap rangsangan. Self management atau pengelolaan diri merupakan suatu strategi pengubahan perilaku yang bertujuan untuk mengarahkan perilaku seseorang dengan suatu teknik atau kombinasi teknik terapeutik.

Self management berkenaan dengan kesadaran dan keterampilan untuk mengatur keadaan sekitarnya yang mempengaruhi tingkah laku individu [12]. Self management adalah suatu proses dimana klien mengarahkan sendiri pengubahan perilakunya dengan satu strategi atau gabungan strategi [13].

Self management bertujuan untuk membantu konseli menyelesaikan masalah, teknik ini menekankan pada perubahan tingkah laku konseli yang dianggap merugikan orang lain. Self management merupakan upaya individu untuk melakukan perencanaan, pemusatan perhatian, dan evaluasi terhadap aktivitas yang dilakukan. Di dalamnya terdapat kekuatan psikologis yang memberi arah pada individu untuk mengambil keputusan dan menentukan pilihannya serta menetapkan cara-cara yang efektif dalam mencapai tujuannya.

Pada dasarnya, pengelolaan diri terjadi ketika seseorang terlibat dalam satu perilaku dan mengendalikan terjadinya perilaku lain (perilaku sasaran) dikemudian waktunya [14]. Self management melibatkan adanya perilaku pengendali dan perilaku yang terkendali. Dalam perilaku pengendali melibatkan penerapan strategi pengelolaan diri dimana anteseden dan konsekuensi dari perilaku terget atau perilaku alternatif yang akan dimodifikasi [15].

Self management merupakan serangkaian teknis untuk mengubah perilaku, pikiran, dan perasaan Berdasarkan uraian di atas, self management merupakan seperangkat prinsip atau prosedur yang meliputi pemantauan diri (self monitoring), reinforcement yang positif (self reward), perjanjian dengan diri sendiri (self contracting), penguasaan terhadap rangsangan (stimulus control) dan merupakan keterkaitan antara teknik cognitive, behavior, serta affective dengan susunan sistematis berdasarkan kaidah pendekatan cognitive behavior therapy, digunakan untuk meningkatkan keterampilan siswa dalam proses kematangan karir yang diharapkan.

\section{TUJUAN SELF MANAGEMENT}

Tujuan dari self management adalah pengembangan perilaku yang lebih adaptif dari konseli. Konsep dasar dari self management adalah : (1) Proses pengubahan tingkah laku dengan satu atau lebih strategi melalui pengelolaan tingkah laku internal dan eksternal individu. (2) Penerimaan individu terhadap program perubahan perilaku menjadi syarat yang mendasar untuk menumbuhkan motivasi individu. (3) Partisipasi individu untuk menjadi agen perubahan menjadi hal yang sangat penting. (4) Generalisasi dan tetap mempertahankan hasil akhir dengan jalan mendorong individu untuk menerima tanggung jawab menjalankan strategi dalam kehidupan sehari-hari. (5) Perubahan bisa dihadirkan dengan mengajarkan kepada individu menggunakan ketrampilan menangani masalah. (6) Agar individu secara teliti dapat menempatkan diri dalam situasi-situasi yang menghambat tingkah laku yang mereka hendak hilangkan dan belajar untuk mencegah timbulnya perilaku atau masalah yang tidak dikehendaki. (7) Individu dapat mengelola pikiran, perasaan dan perbuatan mereka sehingga mendorong pada pengindraan terhadap hal-hal yang tidak baik dan peningkatan hal-hal yang baik dan benar. 


\section{KONSELING BEHAVIORAL DENGAN TEKNIK SELF MANAGEMENT UNTUK MENINGKATKAN KEMATANGAN KARIR SISWA SMK}

Untuk mewujudkan kematangan karir siswa SMK, penulis memilih layanan konseling behavioral melalui teknik Self Management. Self management adalah suatu strategi pengubahan perilaku yang dalam prosesnya klien mengarahkan perubahan perilakunya sendiri dengan suatu teknik atau kombinasi teknik terapetik [13]. Self management merupakan suatu strategi kognitif behavioral, anggapan dasarnya adalah setiap manusia memiliki kecenderungan positif maupun negatif. Segenap perilaku manusia itu merupakan hasil dari proses belajar dalam merespons terhadap berbagai stimulus dari lingkungannya. Namun self management menentang keras pandangan behavioral radikal yang mengatakan manusia itu sepenuhnya dibentuk dan ditentukan oleh lingkungannya. Self management bertujuan untuk rnembantu klien agar dapat mengubah perilaku negatifnya dan mengembangkan perilaku positifnya dengan jalan mengamati diri sendiri: mencatat perilaku-perilaku tertentu (pikiran, perasaan, dan tindakannya) dan interaksinya dengan peristiwa-peristiwa lingkungannya: menata kembali lingkungan sebagai isyarat khusus atau anteseden atas respons tertentu: serta menghadirkan diri dan menentukan sendiri stimulus positif yang mengikuti respons yang diinginkan [13].

Self management memandang klien merupakan individu yang dapat belajar atau mengarahkan diri sendiri sangat ditonjolkan. Oleh karena itu, Self management tepat digunakan dalam mewujudkan kematangan karir siswa SMK. Dengan menggunakan strategi self management, di samping klien dapat nencapai perubahan perilaku sasaran yang diinginkan juga dapat berkembang kemampuan self management.

\section{LANGKAH-LANGKAH TEKNIK SELF-MANAGEMENT}

Adapun tahap-tahap dalam self management sebagai berikut: (1) Konseli mengidentifikasi dan mencatat sasaran perilaku dan mengontrol penyebab serta akibatnya. (2) Konseli mengidentifikasi perilaku yang diharapkan arah perubahannya. (3) Konseli menjelaskan kemungkinan strategi pengelolaan diri (self management). (4) Konseli memilih satu atau lebih strategi self management. (5) Konseli menyatakan secara verbal persetujuan untuk menggunakan strategi self management. (6) Konselor memberikan instruksi dan model strategi yang dipilih. (7) Konseli mengulang pemahaman strategi yang dipilih. (8) Konseli menggunakan strategi yang dipilih. (9) Konseli mencatat penggunaan strategi serta tingkat perilaku sasaran. (10) Data konseli diperiksa oleh konselor bersama konseli dan konseli melanjutkan atau membuat revisi program. (11) Membuat catatan dan penyajian data pada diri sendiri dan penguat demi kemajuan.

\section{SIMPULAN DAN SARAN}

\section{SIMPULAN}

Konseling merupakan proses komunikasi bantuan yang amat penting. Diperlukan model yang dapat menunjukkan kapan dan bagaimana konselor melakukan intervensi kepada klien. Konseling memerlukan keterampilan (skill) pada pelaksanaanya. Teknik konseling berarti seperangkat aturan dan upaya untuk menjalankan praktek bantuan berdasarkan teori dan keterampilan konseling. Teknik konseling self management merupakan seperangkat aturan dan upaya untuk menjalankan praktek bantuan profesional terhadap individu agar mereka dapat mengembangkan potensi dan memecahkan setiap masalahnya dengan mengimplementasikan seperangkat prinsip atau prosedur yang meliputi pemantauan diri (self monitoring), reinforcement yang positif (self reward), perjanjian dengan diri sendiri (self contracting), penguasaan terhadap ransangan (stimulus control) dan merupakan keterkaitan antara teknik cognitive, behavior, serta affective dengan susunan sistematis berdasarkan kaidah pendekatan cognitive behavior therapy, digunakan untuk meningkatkan keterampilan dalam proses pembelajaran yang diharapkan. Secara aplikatif, dapat digunakan pada layanan konseling individual maupun kelompok sesuai dengan kebutuhan. Oleh karena itu dalam mewujudkan kematangan karir siswa SMK dapat digunakan konseling behavioral dengan teknik Self management.

\section{SARAN}

Berdasarkan hasil kejian di atas, maka ada beberapa saran yang dapat digunakan sebagai bahan pertimbangan yaitu: (1) Guru Pembimbing diharapkan dapat melatih siswa dalam bidang karir melalui tahap-tahap yang terdapat dalam layanan bimbingan konseling yang lebih dapat lebih berpengaruh terhadap tingkat kematangan karir siswa. (2) Untuk peneliti lebih lanjut, diharapkan dapat melakukan penelitian yang lebih luas dan komprehensif mengenai penggunaan teknik self management terhadap kematangan karir siswa agar dapat meminimalisir jumlah siswa yang mengalami tingkat kematangan karir rendah.

\section{DAFTAR PUSTAKA}

[1] Santrock, W John. 2003. Adolescence Perkembangan Remaja. Jakarta: Erlangga.

[2] Alvarez, Gonzales M. 2008. Career Maturity: a Priority for Secondary Education. Journal of Research in Educational Psychology. ISSN. 16196 - 2095. No. 16. Vol. 63 2008, PP: 749 772. Spain: Departement of Educational Research Methods and Diagnostics, University of Barcelona.

[3] Prihantoro, Sri. 2007. Program Bimbingan untuk Mengembangkan Kemampuan Perencanaan Karir Remaja. Skripsi. Bandung: Jurusan Bimbingan dan Konseling UPI Bandung. (Online). http://repository.upi.edu diakses 29 Juni 2016.

[4] Nurbaini, Hazar. 2006. Kontribusi Layanan Informasi Karir terhadap Penyelesaian Masalah Karir yang Dihadapi Siswa SMK. Skripsi. Bandung: Jurusan Bimbingan dan Konseling UPI Bandung. (Online). http://repository.upi.edu diakses 29 Juni 2016.

[5] Hasan, B. 2006. Career Maturity of Indians Adolescents as A Function of Self Concept, Vocational Aspiration and Gender. Journal 
of the Indian Academy of Applied Psychology No.2 Vol. 32 February 2006. p.127-134.

[6] Supriatna, Mamat. 2009. Layanan Bimbingan Karir di Sekolah Menengah. Bandung: Departemen Pendidikan Nasional Universitas Pendidikan Indonesia.

[7] Knowles, M.S. 2003. Self Directing Learning: A guide for learner and teachers. Chicago: Follet Publishing Company.

[8] Gunarsa, D. Singgih. 2004. Konseling dan Psikoterapi. Jakarta: Gunung Mulia.

[9] Brown, Duana. 2002. Career Counseling Techniques. Needham Height MA: A Division of Simon \& Schuls Inc.

[10] Savickas, M. L. 2001. A Developmental Perspective on Vocational Behavior: Career Pattern, Salience, and Themes. International Journal for Educational and Vocational Guidance, 1, 49-57.

[11] W. S Winkel \& Sri Hastuti. 2006. Bimbingan dan Konseling di Institusi Pendidikan. Yogyakarta: Media Abadi
[12] Fauzan, Lutfi. 1992. Modul Rancangan Konseling Individual. Malang: Depdikbud IKIP Malang.

[13] Cormier, L.J. \& Cormier, L.S. 1989. Interviewing For Helpers. $2^{\text {nd }}$ Edition. California: Brooks/Cole Publishing Company.

[14] Watson, D. R., \& Tharp, R. G. 2001. Self-directed behavior (8th ed.) Monterey, CA: Brooks/Cole.

[15] Raymond, M.G. 2008. Behavior Modification: Principles and Procedures. University of South Florida. 